\title{
Daya Dukung Lahan Hijauan Makanan Ternak untuk Ternak Sapi Potong di Kampung Bowi Subur, Distrik Masni, Kabupaten Manokwari, Provinsi Papua Barat
}

\author{
Etmundus Ronaldo Ikanubun¹, Ebit Eko Bachtiar¹, Ni Putu Vidia Tiara Timur ${ }^{1}$, Bangkit \\ Lutfiaji Syaefullah $^{1}$, Maria Herawati ${ }^{1}$, Susan Carolina Labatar ${ }^{{ }^{*}}$ \\ ${ }^{1}$ Program Studi Penyuluhan Peternakan dan Kesejahteraan Hewan, Politeknik Pembangunan \\ Pertanian Manokwari \\ *Corresponding author: carolinasusan508@gmail.com
}

\begin{abstract}
Abstrak
Sektor peternakan hingga saat ini masih merupakan salah satu kegiatan dalam pelaksanaan pembangunan yang harus menjadi skala prioritas, karena dengan penggalakkan usaha ini akan dapat mengatasi kekurangan kebutuhan protein hewani. Perkembangan ternak sapi potong sangat berhubungan erat dengan ketersediaan hijauan sebagai sumber pakan ternak. Pakan Ternak merupakan hal terpenting dalam usaha peternakan sapi potong, karena 70-80\% berpengaruh pada produksi, hal ini dikarenakan agar hijauan makanan ternak mampu menunjang hidup ternak agar mencukupi bobot badan ideal ternak sapi potong. Penelitian ini bertujuan untuk mengetahui daya dukung lahan dalam menunjang ketersediaan pakan ternak bagi pengembangan sapi potong yang dipelihara oleh penduduk Kampung Bowi Subur, distrik Masni, kabupaten Manokwari. Penelitian menggunakan metode survei dengan cara pengamatan langsung di lapangan. Hasil gambar peta dari apliasi google earth yang menggunakan citra satelit, kemudian dianalisis mengunakan aplikasi Quantum GIS dan hasilnya peta tersebut akan berisi berbagai informasi tentang luas lahan hijauan dan daya dukung lahan hijauan makanan ternak.
\end{abstract}

Kata kunci: Citra satelit, Daya dukung, Hijauan

\section{Abstract}

The livestock sector is still one of the activities in the implementation of development that must be a priority scale, because by promoting this business it will be able to overcome the shortage of animal protein needs. The development of beef cattle is closely related to the availability of forage as a source of animal feed. Animal feed is the most important thing in the beef cattle business, because $70-80 \%$ has an effect on production, this is because forage forage is able to support livestock life to meet the ideal body weight of beef cattle. This study aims to determine the carrying capacity of land in supporting the availability of animal feed for the development of beef cattle kept by residents of Bowi Subur Village, Masni District, Manokwari Regency. The study used a survey method by direct observation in the field. The results of the map image from the google earth application using satellite imagery, then analyzed using the Quantum GIS application and the results of the map will contain various information about the area of forage land and the carrying capacity of forage land.

Keywords: Carrying capacity, Forage, Satellite image 
Prosiding Seminar Nasional Pembangunan dan Pendidikan Vokasi Pertanian

Politeknik Pembangunan Pertanian Manokwari, 31Juli 2021

e ISSN : 2774-1982

DOI : https://doi.org/10.47687/snppvp.v2i1.202

\section{PENDAHULUAN}

Sektor peternakan hingga saat ini masih merupakan salah satu kegiatan dalam pelaksanaan pembangunan yang harus menjadi skala prioritas, karena dengan penggalakkan usaha ini akan dapat mengatasi kekurangan kebutuhan protein hewani. Peningkatan kualitas sumber daya manusia Indonesia, yang mampu berpikir berkreasi dalam berkarya, hanya akan dapat dicapai bila masyarakat kita telah terpenuhi kebutuhan proteinnya (terutama protein hewani). Sehingga dengan demikian, seluruh masyarakat sebagai peternak, para investor dan terutama bagi pemerintah daerah sebagai penentu kebijakan dalam pembangunan, harus berbuat bersama untuk kesejahteraan bangsanya.

Indonesia adalah negara agraris, dimana data dan informasi lahan merupakan elemen penting untuk pemantauan di bidang pertanian, secara luas seperti pada tanam dan kalender tanam, agar perencanaan pengeloaan dapat dilakukan tepat sasaran dan bijaksana. Informasi sumberdaya lahan berupa data digital baik tabular maupun spasial merupakan salah satu data yang menjadi pertimbangan utama para pembuat kebijakan pada tingkat nasional, produktif dan berkelanjutan, oleh karena itu, diperlukan pelayanan informasi sumber daya lahan yang tepat dan akurat.

Perkembangan ternak sapi potong sangat berhubungan erat dengan ketersediaan hijauan sebagai sumber pakan ternak. Pakan Ternak merupakan hal terpenting dalam usaha peternakan sapi potong, karena $70-80 \%$ berpengaruh pada produksi, hal ini dikarenakan agar hijauan makanan ternak mampu menunjang hidup ternak agar mencukupi bobot badan ideal ternak sapi potong (Labatar dan Wosiri, 2018). Hijauan makanan ternak merupakan salah satu bahan pakan dasar dan utama untuk ternak ruminansia, terutama bagi ternak sapi yang setiap harinya membutuhkan cukup banyak hijauan terutama untuk indukan ternak sapi maupun ternak sapi perah (Udding et al., 2014).

Sapi potong merupakan salah satu ternak yang dipelihara dengan tujuan utama sebagai penghasil daging. Ciri-ciri sapi potong memiliki tubuh besar, kualitas dagingnya maksimum, laju pertumbuhan cepat, efisiensi pakan tinggi, dan mudah dipasarkan (Pawere et al., 2012).

Penelitian ini bertujuan untuk mengetahui daya dukung lahan dalam menunjang ketersediaan pakan ternak bagi pengembangan sapi potong yang dipelihara oleh penduduk kampung Bowi Subur, distrik Masni, kabupaten Manokwari. Penelitian menggunakan metode survei dengan cara pengamatan langsung di lapangan. 
Prosiding Seminar Nasional Pembangunan dan Pendidikan Vokasi Pertanian

Politeknik Pembangunan Pertanian Manokwari, 31Juli 2021

e ISSN : 2774-1982

DOI : https://doi.org/10.47687/snppvp.v2i1.202

Citra satelit merupakan sistem tanpa awak (Unmanned System), yaitu sistem berbasis elektro-mekanik yang dapat melakukan misi-misi terprogram, dengan karakteristik tanpa awak pesawat, beroperasi pada mode mandiri baik secara penuh atau sebagian, Sistem ini dirancang untuk dapat dipergunakan secara berulang (Wikantika, 2009). Satelit yang digunakan oleh google earth adalah satelit landsat, yaitu satelit milik amerika serikat yang telah beroperasi dan memiliki manfaat dalam melakukan pemetaan lahan dan bentuk permukaan bumi (Suwargana, 2013).

Data yang didapatkan dari citra satelit kemudian dimasukan dan diolah dengan GIS atau Sistem Informasi Geografis (Geographic Information System) yaitu sistem informasi khusus yang mengelola data yang memiliki informasi spasial (bereferensi keruangan). Pengertian informasi geografis adalah informasi mengenai tempat atau lokasi, dimana suatu objek terletak di permukaan bumi dan informasi mengenai objek dimana lokasi geografis itu berada untuk dianalisa dalam pengambilan keputusan (Susanto et al., 2016).

\section{METODE}

Lokasi penelitian adalah tempat atau objek untuk dilakukan penelitian. Lokasi penelitian berada di kampung Bowi Subur, distrik Masni, kabupaten Manokwari, provinsi Papua Barat. Lokasi dipilih karena Distrik Masni merupakan daerah dengan populasi ternak sapi terbesar di kabupaten Manokwari dan rata-rata hijauan makanan ternak dibutuhkan oleh ternak ruminansia yaitu ternak sapi. Kampung Bowi Subur dipilh karena belum memiliki peta lahan hijauan makanan ternak. Penelitian dilakukan oleh mahasiswa selama 3 bulan yaitu dimulai dari tanggal 15 Maret - 15 Mei 2021.

Alat dan bahan yang digunakan dalam penelitian ini adalah aplikasi Google Earth, Komputer dengan spesifikasi Intel Core i5 dengan 4 GB RAM 500 GB hard disk VGA Nvidia 610m 2GB, Aplikasi Quantum GIS, data luas lahan Kabupaten Manokwari, oven, timbangan digital, gunting, wadah kue kertas, quadran, sabit, timbangan gantung digital dan alat tulis.

Persiapan Penelitian

Variabel yang diukur dalam penelitian ini adalah sebagai berikut yaitu:

a. Luas Lahan Hijauan Makanan Ternak

Hasil pemetaan dengan menggunakan citra satelit. Luas lahan hijauan makanan ternak diukur dengan menggunakan aplikasi Quantum GIS. Luas lahan yang dilihat hanya yang ditanami HMT. 
Prosiding Seminar Nasional Pembangunan dan Pendidikan Vokasi Pertanian

Politeknik Pembangunan Pertanian Manokwari, 31Juli 2021

e ISSN : 2774-1982

DOI : https://doi.org/10.47687/snppvp.v2i1.202

b. Daya Dukung Lahan

Daya dukung lahan makanan ternak adalah kemampuan suatu wiayah untuk meghasilkan pakan ternak berupa hijauan yang dapat dihasilkan bagi kebutuhan sejumlah popuasi sapi potong bentuk segar maupun kering, tanpa melalui pengelolahan khusus daya dukung hijauan dihitung berdasarkan produksi bahan kering (BK) terhadap kebutuhan satu-satuan ternak (1 ST) dalam satuan hari (Haryono et al., 2002 dalam Hamid, 2012).

$$
\text { Daya Dukung (1 ST) }=\frac{\text { Produksi Bahan Kerng }(\mathrm{kg} / \mathrm{ha})}{\text { Kebutuhan Bahan Kering Ternak }(\mathrm{kg} / \mathrm{ha})}
$$

Satuan Ternak Ashari et al. (1995) yaitu sapi 0,7 ST, kerbau 0,8 ST, domba 0,07 ST, kambing 0,08 ST agar memudahkan dalam melakukan perhitungan.

c. Indeks Daya Dukung Lahan

Daya dukung lahan makanan ternak adalah kemampuan suatu wiayah untuk meghasilkan pakan ternak berupa hijauan yang dapat dihasilkan bagi kebutuhan sejumlah popuasi sapi potong bentuk segar maupun kering, tanpa melalui pengelolahan khusus daya dukung hijauan dihitung berdasarkan produksi bahan kering (BK) terhadap kebutuhan satu-satuan ternak (1 ST) dalam satuan tahun.

$$
I D D=\frac{\text { Daya Dukung Hijauan Makanan Ternak (ST) }}{\text { Jumlah Populasi Ruminansia (ST) }}
$$

Tabel 1. Kriteria Status Daya Dukung Hijauan Berdasarkan IDD.

\begin{tabular}{ccc}
\hline NO & Indeks Daya Dukung (IDD) & Kriteria \\
\hline 1. & $<2$ & Aman \\
2. & $>1,5-2$ & Rawan \\
3. & $>1-1,5$ & Kritis \\
4. & $<1$ & Sangat Kritis \\
\hline
\end{tabular}




\section{HASIL DAN PEMBAHASAN}

\section{Pemetaan Lahan Hijauan Makanan Ternak}

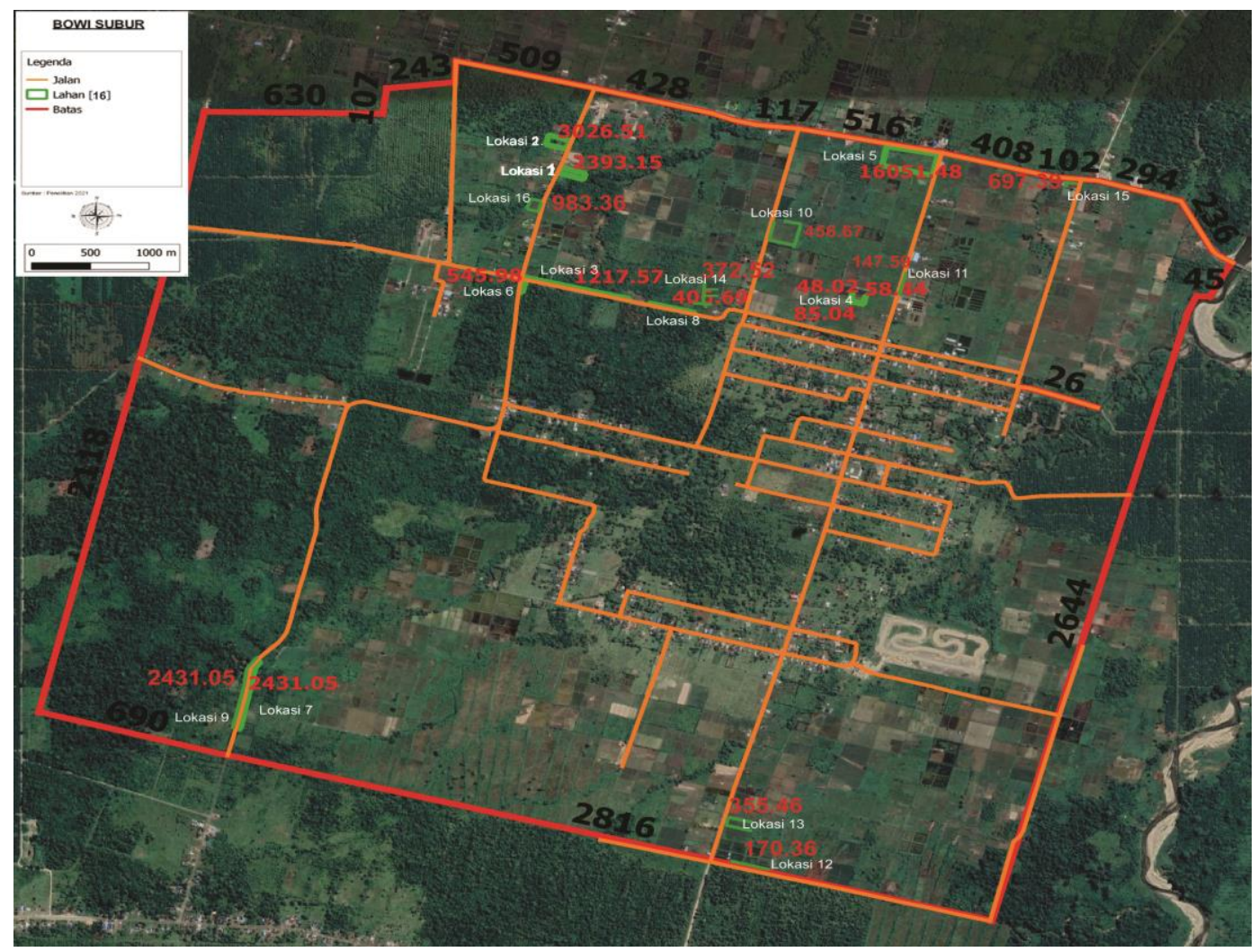

Gambar 1. Analisis Peta Lahan Hijauan Makanan Ternak

Pemetaan lahan hijauan makanan ternak dilakukan dengan menggunakan citra satelit atau menggunakan google earth. Hasil analisis peta Kampung Bowi Subur yaitu, luasan kampung Bowi Subur sebesar 2.200 ha dengan luasan lahan hijauan makanan ternak yang telah diukur yaitu sebanyak 16 lokasi dengan total luasan sebesar 37.894,38 $\mathrm{m}^{2}$ dengan produksi bahan segar sebesar $203.409 \mathrm{~kg} / \mathrm{m}^{2}$ dan produksi bahan kering sebesar $61.607,26 \mathrm{~kg} / \mathrm{m}^{2}$.

Kampung Bowi Subur memiliki luasan lahan yang telah digunakan yaitu 1.077,75 Ha (Tabel 5) sehingga masih terdapat 1.122,25 Ha yang masih belum digunakan.

\section{Daya dukung lahan}

Hasil analisis dari Komposisi botanis di Kampung Sumber Boga dapat dilihat pada lampiran 4. Hasil sampling hijauan pada 16 lokasi lahan hijauan terdapat 25 jenis rumput yang tumbuh secara liar maupun ditanam dan dibudidayakan. Jenis rumput yang ditanam dan dibudidayakan di Kampung Bowi Subur yaitu rumput gajah dan terdapat beberapa yang tumbuh liar seperti tebu-tebuan dan lombok-lombokan. 
Prosiding Seminar Nasional Pembangunan dan Pendidikan Vokasi Pertanian

Politeknik Pembangunan Pertanian Manokwari, 31Juli 2021

e ISSN : 2774-1982

DOI : https://doi.org/10.47687/snppvp.v2i1.202

Mayoritas tanaman rumput yang tumbuh pada lokasi 1 yaitu rumput gajah $20 \%$, lokasi 2 yaitu tanaman sentro 18\%, Lokasi 3 rumput gajah 62,94\%, Lokasi 4 rumput gajah $38,93 \%$, dan lokasi 5 tebu-tebuan $100 \%$, sedangkan lahan hijauan makanan ternak yang dipelihara secara baik dan tidak terdapat tanaman atau rumput lain yang tumbuh hanya terdapat pada lokasi $6,7,8,9,10,11,12,13,14,15,16$ dengan presentase rumput gajah sebesar $100 \%$.

Peternak di kampung Bowi Subur memanfaatkan rumput yang tumbuh disekitar kampung maupun yang sengaja ditanam sebagai pakan ternak sapi potong yang dipelihara. Rumput yang sering diberikan sebagai pakan yaitu jenis gajahan , tebu-tebuan, dan Lombok-lombokan. Setiap pagi dan sore hari peternak mencari hijauan atau rumput disekitar ladang, lahan bekas persawahan maupun lahan hijauan yang dimiliki.

Hasil data komposisi botani pada lampiran 3, kemudian diolah agar dapat mengetahui daya dukung lahan, dan Indeks Daya dukung (IDD) Kampung Bowi Subur. Daya dukung dan indeks daya dukung (IDD) dapat dilihat pada tabel 2.

Tabel 2. Daya Dukung Lahan dan Indeks Daya dukung (IDD)

\begin{tabular}{|c|c|c|c|c|c|c|}
\hline No & Lokasi & $\begin{array}{l}\text { Produksi BK } \\
(\mathrm{Kg}) / \text { Tahun }\end{array}$ & $\begin{array}{c}\text { Jumlah } \\
\text { Ternak } \\
\text { (ST) }\end{array}$ & $\begin{array}{c}\text { Daya } \\
\text { Dukung }\end{array}$ & IDD & Kriteria \\
\hline 1 & 1 & 1523.4522 & \multirow{16}{*}{318,5} & \multirow{16}{*}{0,92} & \multirow{16}{*}{0,0029} & \multirow{16}{*}{ Sangat Kritis } \\
\hline 2 & 2 & 1338.67596 & & & & \\
\hline 3 & 3 & 3118.25364 & & & & \\
\hline 4 & 4 & 277.9272 & & & & \\
\hline 5 & 5 & 618208.6745 & & & & \\
\hline 6 & 6 & 15635.94861 & & & & \\
\hline 7 & 7 & 78596.58554 & & & & \\
\hline 8 & 8 & 81532.49389 & & & & \\
\hline 9 & 9 & 78596.58554 & & & & \\
\hline 10 & 10 & 14764.27993 & & & & \\
\hline 11 & 11 & 4803.870308 & & & & \\
\hline 12 & 12 & 5526.39799 & & & & \\
\hline 13 & 13 & 11595.66256 & & & & \\
\hline 14 & 14 & 12043.68485 & & & & \\
\hline 15 & 15 & 22343.70611 & & & & \\
\hline 16 & 16 & 32042.94294 & & & & \\
\hline & mlah & 981949.1417 & 318,5 & 0,92 & 0,0029 & \\
\hline
\end{tabular}

Berdasarkan tabel 2 dapat dilihat daya tampung ternak sapi di kampung Bowi Subur hanya 0,92 ST/Tahun, sedangkan populasi ternak ruminansia sapi sebesar 318,5 ST, hal ini menyebabkan rendahnya nilai indeks daya dukung sebesar 0,0029. Nilai IDD 
Prosiding Seminar Nasional Pembangunan dan Pendidikan Vokasi Pertanian

Politeknik Pembangunan Pertanian Manokwari, 31Juli 2021

e ISSN : 2774-1982

DOI : https://doi.org/10.47687/snppvp.v2i1.202

rendah kurang dari satu $(<1)$ menunjukkan bahwa pada wilayah tersebut daya dukung pakan hijauan makanan ternak rendah dengan populasi ternaknya yang tinggi menurut Saputra (2016).

Daya dukung pakan hijauan makanan ternak di kampung Bowi subur rendah atau masuk dalam kategori kritis disebakan tingkat produktifitas hijauan makanan ternak yang rendah dan luasan lahan hijauan yang digunakan masih sangat kurang, hal ini disebabkan masyarakat atau peternak tidak melakukan pemeliharaan dan penanaman hijauan makanan ternak secara intensif serta tidak memanfaatkan lahan kosong maupun lahan tidur sebagai lahan hijauan sehingga mempengaruhi ketersediaan pakan, dapat dilihat pada tabel komposisi botanis bahwa hijauan makanan ternak yang telah dipelihara dengan baik sehingga presentase rumput gajah $100 \%$ hanya terdapat di 11 lokasi yaitu lokasi 6,7 , $8,9,10,11,12,13,14,15,16$. Tingkat pendidikan yang cukup rendah pada tabel 3 dengan mayoritas 691 orang tidak sekolah dan 491 orang hanya tamatan SD menjadi penyebab masyarakat atau peternak kurang mengetahui bagaimana melakukan penanaman dan pemeliharaan hijauan makanan ternak secara baik dan benar, mulai dari pemupukan sampai perawatan, hal ini sesuai dengan pendapat Maryam et al. (2016) bahwa tingkat pendidikan mempengaruhi pengetahuan peternak, sehingga peternak kurang produktif dalam usaha peternakannya. Penyuluh peternakan dapat membantu peternak untuk meningkatkan tingkat pengetahuan dan sikap peternak dalam memelihara dan merawat hijauan makanan ternak yang dimiliki.

Luas lahan hijauan makanan ternak menjadi faktor penting dalam melihat daya dukung lahan hijauan karena mempengaruhi tingkat produktifitas hijauan makanan ternak dan mempengaruhi nilai indeks daya dukung. Semakin luas maka jumlah produksi bahan segar dan bahan kering hijauan makanan ternak akan meningkat sehingga mampu menyediakan pakan hijauan sesuai populasi ternak sapi di kampung Bowi Subur.

Kampung Bowi subur memiliki luas lahan sawah pekarangan dan ladang seluas 357,25 Ha sehingga dapat dimanfaatkan untuk menanam lahan hijauan, selain itu masih terdapat 1.122,25 Ha yang masih belum digunakan dan dapat dimanfaatkan sebagai lahan hijauan makanan ternak. 
Prosiding Seminar Nasional Pembangunan dan Pendidikan Vokasi Pertanian

Politeknik Pembangunan Pertanian Manokwari, 31Juli 2021

e ISSN : 2774-1982

DOI : https://doi.org/10.47687/snppvp.v2i1.202

\section{KESIMPULAN DAN SARAN}

Berdasarkan hasil penelitian dan hasil analisis maka dapat disimpulkan bahwa, hasil analisis peta kampung Bowi Subur yaitu luasan Kampung Bowi Subur sebesar 2.200 ha dengan luasan lahan hijauan makanan ternak yang telah diukur yaitu sebanyak 16 lokasi dengan total luasan sebesar $34.204,19 \mathrm{~m}^{2}$ dengan produksi bahan segar sebesar $3.240 .711,318 \mathrm{~kg} / \mathrm{m}^{2}$ dan produksi bahan kering sebesar $981.949,14 \mathrm{~kg} / \mathrm{m}^{2}$.

Daya dukung HMT kampung Bowi Subur terhadap ternak sapi sebesar 0,92 ST/Tahun, sedangkan populasi ternak ruminansia sapi sebesar 318,5 ST, hal ini menyebabkan rendahnya nilai indeks daya dukung sebesar 0,0029, sehingga masuk kriteria sangat kritis, hal ini dikarenakan daya dukung hijauan makanan ternak cukup rendah sedangkan populasi ternak sapi melebihi daya dukung yaitu hanya 0.92 ST dari total populasi $318,5 \mathrm{ST}$, selain itu tingkat pendidikan yang cukup rendah pada tabel 3 menjadi penyebab masyarakat atau peternak kurang mengetahui bagaimana melakukan penanaman dan pemeliharaan hijauan makanan ternak secara baik dan benar.

Berdasarkan hasil penelitian dan kesimpulan serta rencana tindak lanjut maka saran yang diberikan yaitu, masyarakat di kampung Bowi Subur dapat melakukan pemeliharaan Hijauan Makanan Ternak secara intensif dengan memanfaatkan lahan yang ada di sekitar rumah maupun lahan-lahan kosong yang ada di kampung Bowi Subur dan dapat bekerja sama dengan penyuluh peternakan serta dinas pemerintah terkait agar mampu meningkatkan tingkat produksi Hijauan Makanan Ternak dan menambah luasan lahan Hijauan Makanan Ternak sehingga tingkat daya dukung hijauan dapat sesuai dengan jumlah populasi ternak sapi yang ada di kampung Bowi Subur.

\section{DAFTAR PUSTAKA}

Ashari, F., E. Juarini, Sumanto, B. Wibowo, \& Suratman. (1995). Pedoman analisis potensi wilayah penyebaran dan pengembangan peternakan. Balai Penelitian Ternak dan Direktorat Bina Penyebaran dan Pengembangan Peternakan. Jakarta.

Hamid, A.A. (2012). Analisis Potensi Daya Dukung Pengembangan Peternakan Sapi Potong di Kabupaten Pohuwato.Laporan Penelitian Dana APBD Tahun Anggaran 2012. Jurusan Peternakan. Fakultas Ilmu-ilmu Pertanian. Universitas Negeri Gorontalo. Gorontalo.

Labatar, C.S. \& Wosiri G.O. (2018). Pengolahan Jerami Padi dengan Cara Strawmix Sebagai Pakan Ternak Sapi Potong. Jurnal Triton, 9(2).

Maryam. (2016). Analisis Faktor-Faktor yang Mempengaruhi Penentu Pendapatan Usaha Peternakan Sapi Potong (Studi Kasus Desa Otting Kab. Bone). Jurnal Ilmu dan Industri Peternakan. 3(1). 
Prosiding Seminar Nasional Pembangunan dan Pendidikan Vokasi Pertanian

Politeknik Pembangunan Pertanian Manokwari, 31Juli 2021

e ISSN : 2774-1982

DOI : https://doi.org/10.47687/snppvp.v2i1.202

Pawere, F.R., Baliarti, E., \& Nurtini, S. (2012). Proporsi Bangsa, Umur, Bobot Badan Awal Dan Skor Kondisi Tubuh Sapi Bakalan Pada Usaha Penggemukan. Buletin Peternakan, 36: 193-198.

Saputra, J.I. (2016). Analisis potensi daya dukung pengembangan peternakan sapi potong di Kabupaten Pesawaran. Skripsi. Fakultas Pertanian. Universitas Lampung. Bandar Lampung.

Susanto, A., K. Ahmad, \& K. Tutiek. (2016). Sistem Informasi Geografis Pemetaan Lahan Pertanian Dan Komoditi Hasil Panen Kabupaten Kudus. Jurnal Informatika Vol. 10, No. 2.

Suwargana, N. (2013). Resolusi Spasial, Temporal Dan Spektral Pada Citra Satelit Landsat, Spot Dan Ikonos. Jurnal Ilmiah Widya, 1(2): 167 - 174.

Udding, R., B. Nohong \& Munir. (2014). Analisis Kandungan Protein Kasar (PK) dan Serat Kasar Kombinasi Rumput Gajah (Pannisetum purpureum) dan Tumpi Jagung yang Terfermentasi. Jurnal Galung Tropika, 3: 201-207.

Wikantika, K. (2009). Unmanned Mapping Technology: Development and Applications. Workshop Sehari "Unmanned Mapping Technology: Development and Applications" (UnMapTech2008). Bandung, Indonesia. 